
THEK@REAN S๑CIETY Journal of Electrochemical Science and Technology

\title{
High Alloying Degree of Carbon Supported Pt-Ru Alloy Nanopar- ticles Applying Anhydrous Ethanol as a Solvent
}

Kwang-Hyun Choi, Kug-Seung Lee, Tae-Yeol Jeon, Hee-Young Park, Namgee Jung, Young-Hoon Chung and Yung-Eun Sung ${ }^{\dagger}$

World Class University (WCU) program of Chemical Convergence for Energy \& Environment $\left(C_{2} E_{2}\right)$, School of Chemical and Biological Engineering, College of Engineering and Research Center for Energy Conversion \& Storage, Seoul National University (SNU), Seoul 151-744, South Korea

\begin{abstract}
:
Alloying degree is an important structural factor of PtRu catalysts for direct methanol fuel cells (DMFC). In this work, carbon supported PtRu catalysts were synthesized by reduction method using anhydrous ethanol as a solvent and $\mathrm{NaBH}_{4}$ as a reducing agent. Using anhydrous ethanol as a solvent resulted in high alloying degree and good dispersion. The morphological structure and crystallanity of synthesized catalysts were characterized by X-ray diffraction (XRD), high resolution transmission electron microscope (HR-TEM). CO stripping and methanol oxidation reaction were measured. Due to high alloying degree catalyst prepared in anhydrous ethanol, exhibited low onset potential for methanol oxidation and negative peak shift of $\mathrm{CO}$ oxidation than commercial sample. Consequently, samples, applying ethanol as a solvent, exhibited not only enhanced $\mathrm{CO}$ oxidation, but also increased methanol oxidation reaction (MOR) activity compared with commercial PtRu/C (40 wt $\%$, E-tek) and $40 \mathrm{wt} \% \mathrm{PtRu} / \mathrm{C}$ prepared in water solution.
\end{abstract}

Keywords : Direct methanol fuel cell, Platinum, Ruthenium, Ethanol, Alloying degree.

Received August 6, 2010 : Accepted August 16, 2010

\section{Introduction}

A fuel cell is an electrochemical device that can convert the chemical energy of a reaction directly into the electrical energy. It has many advantages, for example low emission of pollutants, higher energy efficiency and reliability. The reaction mechanism of fuel cell system is between hydrogen and oxygen. DMFC consists of an anode where methanol is electro-oxidized to $\mathrm{CO}_{2}$ through the reaction $\left(\mathrm{CH}_{3} \mathrm{OH}+\right.$ $\left.\mathrm{H}_{2} \mathrm{O} \rightarrow \mathrm{CO}_{2}+6 \mathrm{H}^{+}+6 \mathrm{e}^{-}\right)$and a cathode at which oxygen (usually as air) is reduced to water $\left(3 / 2 \mathrm{O}_{2}+6 \mathrm{e}^{-}+6 \mathrm{H}^{+}\right.$ $\rightarrow 3 \mathrm{H}_{2} \mathrm{O}$ )

The conditions required for the anode catalyst of DMFC are as follow; (i) rapid oxidation of methanol in

Corresponding author. Tel.: +82-2-880-1889

E-mail address: ysung@snu.ac.kr anode catalyst (ii) high CO oxidation. Initially, pure Pt has received a grave matter of concern as the anode fuel cell catalyst. However, $\mathrm{Pt}$ is an expensive catalyst compared with other metallic catalysts and it is weak to depress the adsorption of $\mathrm{CO}$ formed during the methanol oxidation. Hence, solution to reduce the adsorption of $\mathrm{CO}$ were found in the alloying of $\mathrm{Pt}$ with other metals such as $\mathrm{Rh},{ }^{1)} \mathrm{Ru},{ }^{2-3}$ ) and $\mathrm{Sn}^{4)}$ This resulted in significant increases of the $\mathrm{CO}$ tolerance of the Pt-alloy anode catalysts. Recently, PtRu alloys are still commonly acknowledged as the best anode electrocatalyst for both the oxidation of $\mathrm{CO}$ and for the oxidation of methanol in DMFCs. In case of methanol electrooxidation, the adsorbed $\mathrm{CO}$, generated by methanol adsorption, has an adverse effect on the electrocatalytic activity of the anode catalyst. The removal of adsorbed $\mathrm{CO}$ is the rate-determining step at potentials under $0.5 \mathrm{~V}$ (vs. reference hydrogen electrode (RHE)). Conversely, at 
higher potentials, the adsorption of methanol commences to determine the overall rate. ${ }^{3)}$

The catalytic effect of PtRu, the 'bifunctional mechanism' and 'ligand (electronic) effect' is mainly discussed. The role of $\mathrm{Ru}$ is to supply oxygen pertaining species to $\mathrm{CO}$ adsorbed Pt sites. The bifunctional mechanism, a system suggested by Watanabe and Motoo, ${ }^{5}$ shows a maximized $\mathrm{CO}$ molecule oxidation on a Pt surface modified by alloyed $\mathrm{Ru}$. In comparison with pure Pt, the onset of the CO oxidation current of $\mathrm{Ru}$ commences at considerably more negative potential $(0.25 \mathrm{~V})$. The $\mathrm{CO}$ oxidation difference between these two metal catalysts is due to the intrinsic characteristic of oxygen adsorption. Ru adsorbs oxygen containing species at potentials as low as $0.2 \mathrm{~V}$ and $\mathrm{Pt}$ adsorbs that at around $0.7 \mathrm{~V}^{3)}$

The ligand effect is verified from $\mathrm{Ru}$ adsorbed on $\mathrm{Pt}$ surfaces which modies the electronic structure of nearby $\mathrm{Pt}$ atoms, with consequences for electrocatalysis on $\mathrm{Pt} / \mathrm{Ru}$ surfaces. ${ }^{6-10)}$ These changes in electronic structure have a number of implications for electrocatalysis. For instance, methanol dehydrogenation on Pt sites (before oxidation to $\mathrm{CO}_{2}$ ) has been shown to occur at lower potential on $\mathrm{Pt} / \mathrm{Ru}$ surfaces. ${ }^{10,11)}$ Also, CO adsorption on Pt sites near $\mathrm{Ru}$ is weakened as compared with pure $\mathrm{Pt}$, which may decrease the uptake of $\mathrm{CO}$ when the electrode is exposed to small quantities of $\mathrm{CO}$ gas and may also facilitate oxidative removal of $\mathrm{CO}$. The emerging consensus seems to be that the ligand effect is less important than the bifunctional mechanism. ${ }^{12-17)}$ Masel and Wieckowski groups concluded that about $20 \%$ of the enhancement in CO oxidation contributed by Ru deposition is ascribed to the ligand effect, while the remaining $80 \%$ of the enhancement is due to the bifunctional mechanism. ${ }^{12,15)}$

Bifunctional effect can be enhanced by high allyoing degree of the Pt and Ru. There were many methods for further improvement of high alloying degree of PtRu performance: (i) colloidal chemistry method (ii) impregnation method (iii) polyol method. In this work, PtRu/C was prepared by reduction method using $\mathrm{NaBH}_{4}$ as a reducing agent. Reduction method has some merits; easy process to prepare the catalyst, synthesis available at low temperature compared to polyol method and shortening of the reaction time. In traditional $\mathrm{NaBH}_{4}$ reduction method, water was used as a solvent. However, in the reaction system if water reacts with Ru precursors $\mathrm{RuOH}$ come into existence as a byproduct. Thus, it is believed that this rapid reaction of Ru catalyst with water leads to a poor alloying degree. ${ }^{18)}$ To overcome this problem, water was replaced to anhydrous ethanol. $40 \mathrm{wt} \% \mathrm{PtRu} / \mathrm{C}$ prepared in anhydrous ethanol showed higher $\mathrm{CO}$ oxidation and MOR activities than commercial PtRu/C (40 wt $\%$, E-tek) and $40 \mathrm{wt} \% \mathrm{PtRu} / \mathrm{C}$ prepared in water solution. In particular, the alloying degree and morphology of the catalyst was investigated by XRD. and the enhancement of $\mathrm{CO}$ oxidation and MOR was elucidated by $\mathrm{CV}$.

\section{Experimental}

\subsection{Synthesis of PtRu/C}

The carbon supported $40 \mathrm{wt} \%$ PtRu alloy nanoparticles were prepared by using a chemical reduction process. Metal chemicals were purchased from Aldrich and sodium borohydride (NaBH4) was obtained from Samchun chemicals. To prepare PtRu catalyst with atomic ratio of $1: 1$ and the total content of $40 \mathrm{wt} \%$, the appropriate amounts of metal precursors were applied. $\mathrm{H}_{2} \mathrm{PtCl}_{6} \cdot \mathrm{xH}_{2} \mathrm{O}$ $(0.1125 \mathrm{~g})$ and $\mathrm{RuCl}_{3} \cdot \mathrm{xH}_{2} \mathrm{O}(0.0483 \mathrm{~g})$ were dissolved into the $300 \mathrm{ml}$ of anhydrous ethanol. The solution was stirred for several minutes. After several minutes, $\mathrm{NaBH}_{4}$ $(0.0851 \mathrm{~g})$ was poured into the vigorous stirring precursor solution. After $5 \mathrm{hrs}$ of reducing the prepared catalyst was filtered and washed with D.I. water, and then dried in an air oven at $60^{\circ} \mathrm{C}$ for $24 \mathrm{hr}$. $40 \mathrm{wt} \% \mathrm{PtRu} / \mathrm{C}$ catalyst was synthesized by D.I. water in comparison with anhydrous ethanol. $\mathrm{H}_{2} \mathrm{PtCl}_{6} \cdot \mathrm{xH}_{2} \mathrm{O}$ as Pt precursors and $\mathrm{RuCl}_{3} \cdot \mathrm{xH}_{2} \mathrm{O}$ as $\mathrm{Ru}$ precursor were dissolved in $300 \mathrm{ml}$ D.I. water. Further procedure is same as the synthesis in anhydrous ethanol. The prepared samples were tabulated in Table 1.

\subsection{Characterization}

Transmission electron microscopy (TEM) images were obtained from a JEOL 2010 operated at $200 \mathrm{kV}$. Examination samples were prepared by dispersing the catalyst powder into the ethanol. Subsequently, $10 \mathrm{ul}$ of catalyst solution was dropped onto a carbon-coated copper grid and then dried in an oven at 60 for a day. A powder X-ray diffraction (XRD) patterns were recorded by Rigaku D/MAX 2500 operated with a Cu Ka source $(\lambda=1.541 \AA)$ at $40 \mathrm{kV}$ and $200 \mathrm{~mA}$. The angle extended from $20^{\circ}$ to $80^{\circ}$ and the scan rate was $2^{\circ}$ per minute. Cyclic voltammogram was obtained in a conventional three-electrode electrochemical cell using a glassy carbon (GC) electrode

Table 1. Naming of the samples

\begin{tabular}{cccc}
\hline sample & solvent & Pt precursor & Ru precursor \\
\hline A1 & Water & $\mathrm{H}_{2} \mathrm{PtCl}_{6} \mathrm{xH}_{2} \mathrm{O}$ & $\mathrm{RuCl}_{3} \times \mathrm{H}_{2} \mathrm{O}$ \\
$\mathrm{A} 2$ & Ethanol & $\mathrm{H}_{2} \mathrm{PtCl}_{6} \mathrm{xH}_{2} \mathrm{O}$ & $\mathrm{RuCl}_{3} \mathrm{xH}_{2} \mathrm{O}$ \\
\hline
\end{tabular}


as a working electrode, and Pt wire and saturated calomel electrode as a counter and a reference electrode, respectively. Electrochemical measurements were all recorded and reported vs. normal hydrogen electrode (NHE). The ink slurry was prepared by mixing carbon-supported nanoparticles, a $5 \mathrm{wt} \%$ Naon solution (Aldrich Chem. Co), and 2-propanol. The ratio of contents in the catalyst ink was $20 \mathrm{ul}$ of DI water, $100 \mathrm{ul}$ of Naon solution and $1 \mathrm{ml}$ of 2-propanol per $0.01 \mathrm{~g}$ of catalysts. The $10 \mathrm{ul}$ of catalyst ink was dropped onto a glassy carbon electrode using a micropipette, and then dried in a vacuum oven for $15 \mathrm{~min}$. Electrochemical experiments were performed with an Autolab general purpose electrochemical system (Eco Chemie). Electrochemical measurement was conducted in $0.5 \mathrm{M} \mathrm{H}_{2} \mathrm{SO}_{4}$ solution that was purged with nitrogen gas for $30 \mathrm{~min}$ prior to each test. Subsequently, three consecutive scans were performed in the potential range $0.05-0.8 \mathrm{~V}$ vs. NHE at a scan rate of $20 \mathrm{mV} / \mathrm{s}$. Solutions of $0.5 \mathrm{M} \mathrm{H}_{2} \mathrm{SO}_{4}$ and $1 \mathrm{M} \mathrm{CH}_{3} \mathrm{OH}+0.5 \mathrm{M} \mathrm{H}_{2} \mathrm{SO}_{4}$ were purged with Ar gas prior to taking measurements. Platinum wire and saturated calomel electrode (SCE) were used as the counter and reference electrode, respectively. In order to identify the activities of the electrocatalysts, cyclic voltammetry $(\mathrm{CV})$ was conducted at potentials between 0.05 and $0.8 \mathrm{~V}$ vs. NHE at a scan rate of $20 \mathrm{mV} / \mathrm{s}$. $\mathrm{CO}$ stripping voltammetry and methanol oxidation were performed at potentials between 0.05 and $1.0 \mathrm{~V}$ vs. NHE at a scan rate of $20 \mathrm{mV} / \mathrm{s}$. The $\mathrm{CO}$ stripping was observed by measuring desorption efficiency of pre-adsorbed $\mathrm{CO}$. $\mathrm{CO}$ gas was adsorbed on the catalyst at a potential of $0.1 \mathrm{~V}$ vs. NHE by bubbling a $0.5 \mathrm{M} \mathrm{H}_{2} \mathrm{SO}_{4}$ solution with $10 \% \mathrm{CO} / \mathrm{He}$ gas for $30 \mathrm{~min}$ and then the dissolved $\mathrm{CO}$ gas in the solution was removed by bubbling with $\mathrm{Ar}$ gas for $30 \mathrm{~min}$. All electrochemical experiments were performed at room temperature.

\section{Results and Discussion}

\subsection{Preparation and Structural Characterization}

Anhydrous ethanol was used as a solvent for synthesis of the Pt-Ru bimetallic catalyst, which contains properties of low oxide and high degree of alloying. It is known that carbon particle dispersion is better in anhydrous ethanol rather than water. The reason for different degree of dispersion of carbon between these two solvent can be deduced from higher donor number of alcohol in comparison with water. ${ }^{27)}$ To promote reduction in anhydrous solvent $\mathrm{H}_{2} \mathrm{PtCl}_{6} \cdot \mathrm{xH}_{2} \mathrm{O}$ and $\mathrm{RuCl}_{3} \cdot \mathrm{xH}_{2} \mathrm{O}$ was chosen as a $\mathrm{Pt}$ and $\mathrm{Ru}$ precursors. TEM images of the PtRu/C
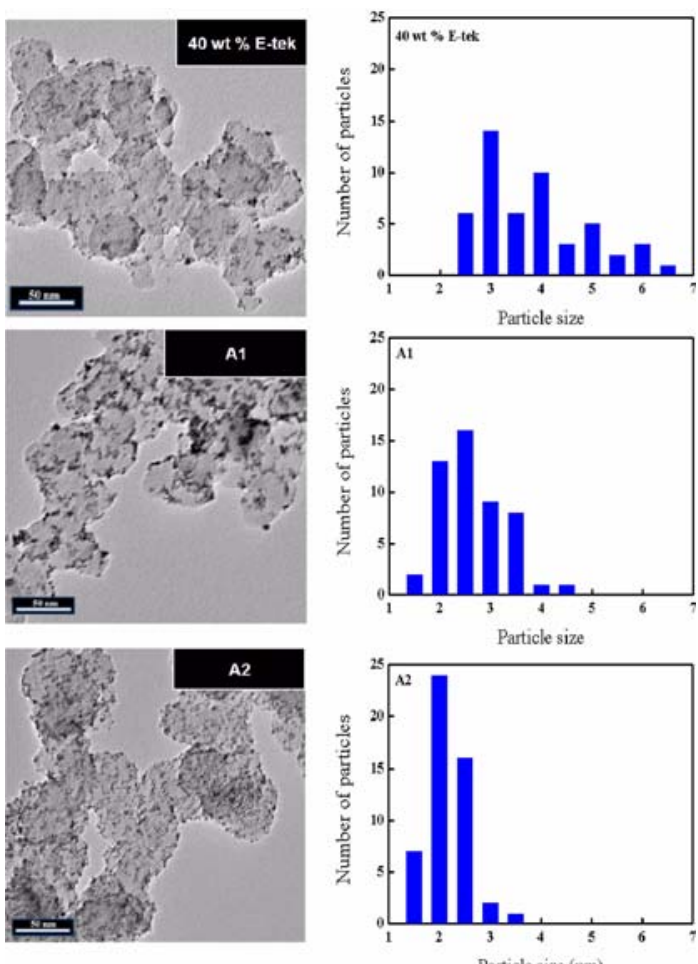

Fig. 1. TEM image of particle size distribution of A1, A2, and E-tek.

catalysts were obtained in order to survey morphological structures of nanoparticles, and are shown in Fig. 1. The nanoparticles prepared in water solution and the commercial nanoparticles were harshly agglomerated on the carbon support with a particle size of 2-5 nm. By contrast, the catalyst synthesized in anhydrous ethanol solvent shows a good dispersion of nanoparticles. Mean diameters of commercial, A1 and A2 examined from TEM are $4.1 \mathrm{~nm}, 3.2 \mathrm{~nm}$ and $2.4 \mathrm{~nm}$, repectively. XRD profiles of the prepared $40 \mathrm{wt} \% \mathrm{PtRu} / \mathrm{C}$ samples are shown in Fig. 2. The average particle size was obtained by applying the Debye-Scherrer equation (E1);

$$
d=\frac{0.94 \times \lambda \kappa_{\alpha 1}}{B_{(2 \theta)} \times \cos \theta_{\max }}
$$

$\mathrm{d}$ is the mean size of the PtRu particles. $\lambda \kappa_{\alpha 1}$ is the wavelength of X-ray (1.5418 $\AA$ ), $\theta_{\max }$ indicates the angle at the maximum, and $\beta_{2 \theta}$ is the width of the peak at half height. $\mathrm{q}_{\max }$ and $\beta_{2 \theta}$ were determined with OriginPro 8.0 program. The (220) peak was chosen to evaluate the particle size and shift of the peak. Because it is obvious that (220) peak does not have any neighboring peaks 

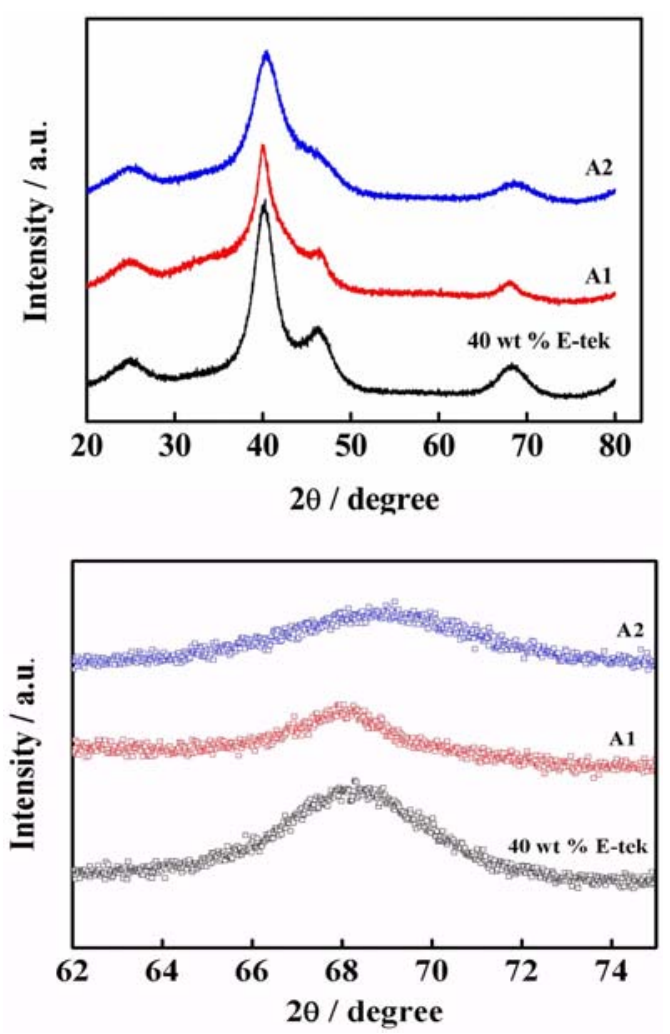

Fig. 2. X-ray diffraction patterns of as-synthesized and commercial $40 \mathrm{wt} \% \mathrm{PtRu} / \mathrm{C}$.

such as a carbon peak. As shown in Fig. the $2 \theta$ of the (220) peak for A1, A2 and commercial are 68.01, 68.88, and 68.27, respectively. Comparing the (110) peak positions of the PtRu with (110) peak position of $\mathrm{Pt}$ XRD profile manifests that $\mathrm{Pt}$ and $\mathrm{Ru}$ did form alloy structures. The as prepared samples showed peak shifts to higher angle than commercial sample. Sample A2 exhibited the highest peak angle. A simple method to obtain the alloying degree of $\mathrm{PtRu} / \mathrm{C}$ catalysts is to calculate the lattice constant changed by alloying. To confirm the change in the lattice parameter, XRD measurements were thoroughly performed as explained in the experimental section. Antolini et al. have proposed that the alloying degree of PtRu catalyst is the $\mathrm{Ru}$ atomic fraction $(\mathrm{xRu})$ in the PtRu alloy. ${ }^{19-21)}$

$$
\begin{aligned}
a(220) & =\frac{\sqrt{2} \lambda_{\mathrm{\kappa} \alpha}}{\sin \theta_{\max }} \\
\left(\lambda_{\mathrm{\kappa} \alpha}\right. & =1.54056 \AA) \\
\mathrm{a} & =\mathrm{a}_{0}-0.124 \mathrm{xRu}
\end{aligned}
$$

Table 2. Summary of the XRD analysis of PtRu/C samples

\begin{tabular}{ccccc}
\hline sample & $\begin{array}{c}\text { Peak } \\
\text { position } \\
(2 \theta)\end{array}$ & $\begin{array}{c}\text { Lattice } \\
\text { parameter } \\
(\AA)\end{array}$ & $\begin{array}{c}\mathrm{M}_{\mathrm{Ru}} \\
(\%)\end{array}$ & $\begin{array}{c}\text { Alloying } \\
\text { degree } \\
(\%)\end{array}$ \\
\hline $40 \mathrm{wt} \%$ E-tek & 68.27 & 3.883 & 26.53 & 36.11 \\
$\mathrm{~A} 1$ & 68.01 & 3.896 & 16.05 & 19.12 \\
$\mathrm{~A} 2$ & 68.77 & 3.858 & 46.53 & 87.02 \\
\hline
\end{tabular}

The proposition was $\mathrm{xRu}$ in the PtRu alloy is indispensable term when defining the alloying degree of $\mathrm{PtRu}$, which is related to the lattice parameter through the equation described above. In the equation E3 $\mathrm{a}_{0}$ is the lattice constant of pure Pt. Value of $\mathrm{a}_{0}$ constant is classified in two cases. First in the case of unsupported Pt, $\mathrm{a}_{0}=0.39231 \mathrm{~nm}$ second for carbon supported Pt, $\mathrm{a}_{0}=0.39155 \mathrm{~nm}$. Therefore, in this study $\mathrm{a}_{0}=0.39155 \mathrm{~nm}$ was chosen. The level of alloying degree was verified by equation 3 .

$$
\begin{aligned}
& \text { a.d. }=\frac{x R u}{\left(1-x_{R u}\right)(R u / P t)_{\text {nom }}} \\
& (R u / P t) \text { nom }=1 \quad \text { nominal Ru/Pt atomic ratio }
\end{aligned}
$$

While adjusting $\mathrm{E} 4$ to the $40 \mathrm{wt} \% \mathrm{PtRu} / \mathrm{C}$ samples $(\mathrm{Ru} / \mathrm{Pt})_{\text {nom }}$ is $1 .^{18,19)}$ Table 2 summarizes the alloying degree of samples, the lattice parameter values obtained from the XRD data, and the average particle diameters obtained from HR-TEM. It can be interpreted that, whereas the only trace change of the particle size, substantial change of the alloying degree. Comparing sample A2 with the $40 \mathrm{wt} \%$ E-tek, the peak angles are shifted to higher angle approximately 0.5 degree. This means that A2 alloying degree is better than that of $40 \mathrm{wt} \%$ E-tek.

\subsection{Electrochemical characterization}

The surface characteristic of PtRu/C was defined by using cyclic voltammetry in an Ar saturated $0.5 \mathrm{M} \mathrm{H}_{2} \mathrm{SO}_{4}$ solution as shown in Fig. 18. Current/potential curves were obtained by electrodes cycled between 0.05 and $0.8 \mathrm{~V}$ at the scan rate of $20 \mathrm{mV} / \mathrm{s}$ and were normalized by the PtRu mass in the catalysts. The peaks for the adsorption/ desorption of hydrogen (normalized by PtRu mass) are clearly shown in Fig. 3. The perimeter of hydrogen peaks, compared with $\mathrm{Pt} / \mathrm{C}$, proves the existence of $\mathrm{Ru}$ on the surface, which initiates the oxygenation of $\mathrm{Ru}$ in low potential (0.05-0.3 V). Thus PtRu nanoparticle electrodes have a very thick double layer due to the $\mathrm{RuOH}^{22}{ }^{22} \mathrm{Pt}$ precursor reduction rate is whole lot faster than $\mathrm{Ru}$ precursor reduction rate. Due to the difference of this 


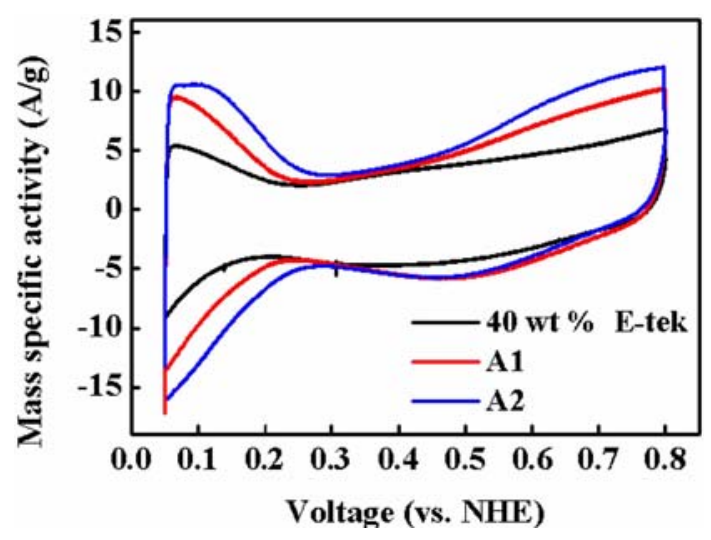

Fig. 3. Cyclic voltammograms of $40 \mathrm{wt} \% \mathrm{PtRu} / \mathrm{C}$ in the $\mathrm{Ar}$ purged $0.5 \mathrm{M} \mathrm{H}_{2} \mathrm{SO}_{4}$ with scan rate of $20 \mathrm{mV} / \mathrm{s}$.

reaction rate $\mathrm{Ru}$ particles tend to cover the surface of $\mathrm{Pt}$. Hence, well poised reduction rate method can render the PtRu catalyst into a higher alloyed form. A2 exhibits the largest hydrogen adsorption/desorption area compared with the rest of the samples. This means that anhydrous ethanol reduces reduction sample $\mathrm{A} 2$ are well alloyed catalysts. $\mathrm{CO}$ stripping analysis was carried out in $0.5 \mathrm{M} \mathrm{H}_{2} \mathrm{SO}_{4}$ to investigate the $\mathrm{CO}$ tolerance and the electrochemical active surface area (EAS) of the catalysts. The results normalized by PtRu mass are shown in Fig. 4. The CO stripping peak positions and electrochemical surface areas (normalized by PtRu mass) calculated using CO stripping area are tabulated in Table 3. The peak positions and onset potentials of the $40 \mathrm{wt} \% \mathrm{PtRu} / \mathrm{C}$ synthesized in ethanol solvent were lower than that of commercial $\mathrm{PtRu} / \mathrm{C}$ and $\mathrm{PtRu} / \mathrm{C}$ synthesized in water solvent. This result indicates that alloying degree affects the catalytic activity

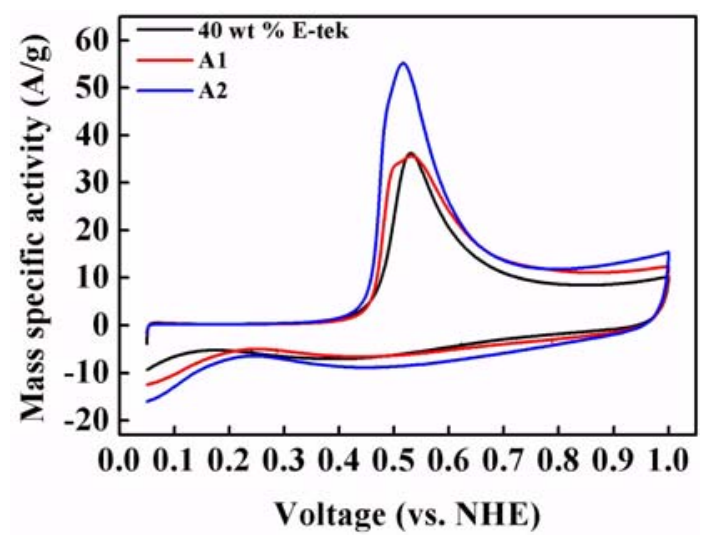

Fig. 4. $\mathrm{CO}$ stripping analysis: $40 \mathrm{wt} \% \mathrm{PtRu} / \mathrm{C}$ samples (0.5 $\mathrm{M} \mathrm{H}_{2} \mathrm{SO}_{4}$ scan rate: $20 \mathrm{mV} / \mathrm{s}$ ).
Table 3. Peak potential and EAS of all PtRu/C samples

\begin{tabular}{ccc}
\hline sample & peak potential $(\mathrm{V})$ & $\mathrm{EAS}_{\mathrm{co}}\left(\mathrm{g} / \mathrm{cm}^{2}\right)$ \\
\hline $40 \mathrm{wt} \%$ E-tek & 0.529 & 553 \\
$\mathrm{~A} 1$ & 0.536 & 625 \\
$\mathrm{~A} 2$ & 0.516 & 781 \\
\hline
\end{tabular}

of CO oxidation. ${ }^{23)}$ Because the well alloyed PtRu catalyst can form surface oxygen containing species at lower potential in comparison with other not well alloyed PtRu catalysts. The difference in peak current can be explained by the surface composition of PtRu catalyst. PtRu catalyst which surface is formed with Pt and Ru metal a lot of CO can adhere to the metal surface in contrast with that of PtRu catalyst formed with Pt and Ru oxide. Therefore, sample A1 has less Ru oxide than A2 and E-tek.

\subsection{Methanol electro-oxidation}

Methanol oxidation on $40 \mathrm{wt} \% \mathrm{PtRu} / \mathrm{C}$ was compared in the following aspects to elucidate the catalytic performance; onset potential of methanol oxidation and the peak current density of methanol oxidation. The methanol electrocatalytic activity of PtRu on carbon support was measured in a solution of $0.5 \mathrm{M} \mathrm{H}_{2} \mathrm{SO}_{4}+1 \mathrm{M} \mathrm{CH}_{3} \mathrm{OH}$. The oxidation current was normalized by PtRu mass and potential was given in the range of 0.05-1 V. Specific activities for methanol oxidation have been known, to be influenced by CO stripping characteristics and mass specific active areas. Higher PtRu alloying degree and an optimum surface structure are desirable for obtaining better $\mathrm{CO}$ tolerance and enhanced mass specific activity for methanol oxidation. ${ }^{24)}$

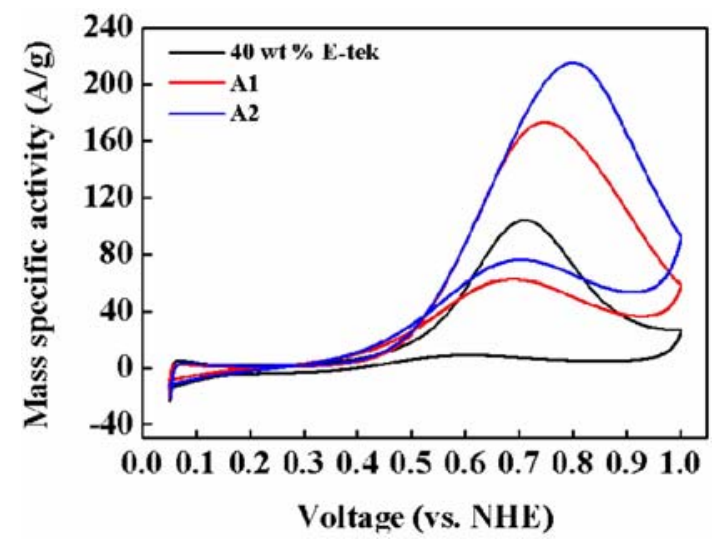

Fig. 5. Cyclic voltammetric ananlysis of $40 \mathrm{wt} \% \mathrm{PtRu} / \mathrm{C}$ for methanol oxidation reaction. $\left(0.5 \mathrm{M} \mathrm{H}_{2} \mathrm{SO}_{4}+1 \mathrm{M} \mathrm{MeOH}\right.$ scan rate: $20 \mathrm{mV} / \mathrm{s}$ ) 
As shown in Fig. 5 the MOR activities for $40 \mathrm{wt} \%$ $\mathrm{PtRu} / \mathrm{C}$ can therefore be ordered as $\mathrm{A} 2>\mathrm{A} 1>$ commercial. Sample A2 manifests the best MOR performance and the lowest onset potential compared with the other samples. This result can be interpreted as A2 is the most well alloyed sample.

\section{Conclusions}

$40 \mathrm{wt} \%$ of PtRu nanoparticles supported on carbon were prepared by $\mathrm{NaBH}_{4}$ reduction method in anhydrous ethanol solvent to achieve high alloying degree. The size of the nanoparticles prepared in this method was determined by Debye-Scherrer equation. The as synthesized electrocatalyst $2 \theta$ (220) peak shift to higher angle is notable from XRD analysis data. The alloying degree of each samples were measured by applying equation Antolini et al. have proposed. The result was perceived that using ethanol as a solvent showed greater alloying degree. Cyclic voltammograms analysis manifest that PtRu alloys were formed in comparison with pure Pt cyclic voltammogram. The CO stripping peak position of the ethanol synthesized PtRu/C shifted to the negative potential in comparison with commercial sample and water synthesized PtRu/C. Therefore, from the results of CO stripping it can be clarified that $\mathrm{CO}$ poisoning of anode catalyst of DMFC can be inhibited using ethanol reduction method.

$40 \mathrm{wt} \% \mathrm{PtRu} / \mathrm{C}$ synthesized in anhydrous ethanol showed considerable increase in $\mathrm{CO}$ oxidation and methanol oxidation reaction than commercial sample.

\section{Acknowledgments}

This research was supported by WCU (World Class University) program through the National Research Foundation of Korea funded by the Ministry of Education, Science and Technology (R31-10013). This work was supported by the Ministry of Commerce, Industryand Energy, the KOSEF through the Research Center for Energy Conversion \& Storage and the Korea Research Foundation (Grant \# KRF-2006-005-J04601).

\section{References}

1. P.N. Ross, K. Kinoshita, A.J. Scarpellino, and P.J. Stonehart, J. Electroanal. Chem., 59, 177 (1975).
2. P.N. Ross, K. Kinoshita, A.J. Scarpellino, and P.J. Stonehart, J. Electroanal. Chem., 63, 97 (1975).

3. H.A. Gasteiger, N.M. Markovic, and P.N. Ross, JR., J. Phys. Chem., 99, 8290 (1995).

4. K. Wang, H.A. Gasteiger, N.M. Markovic, and P.N. Ross, Electrochim. Acta. 41, 2587 (1996).

5. M. Watanabe and S. Motoo, J. Electroanal. Chem., 60, 275 (1975).

6. C. Lu and R.I. Masel, J. Phys. Chem. B, 105, 9793 (2001).

7. G. Samjeske, X.Y. Xiao, and H. Baltruschat, Langmuir, 18, 4659 (2002)

8. Y.Y. Tong, H.S. Kim, P.K. Babu, P. Waszczuk, A. Wieckowski, and E. Oldfield, J. Am. Chem. Soc., 124, 468 (2002).

9. T. Iwasita, F.C. Nart, and W. Vielstich, Bunsenges Phys. Chem.Chem. Phys, 94, 1030 (1990).

10. M. Krausa and W. Vielstich, J. Electroanal. Chem., 379, 307 (1994).

11. T. Iwasita, H. Hoster, A. John-Anacker, W.F. Lin, and W. Vielstich, Langmuir, 16, 522 (2000).

12. A.A. El-Shafei, R. Hoyer, L.A. Kibler, and D.M. Kolb, J. Electrochem. Soc., 151, 141 (2004).

13. J.C. Davies, B.E. Hayden, and D.J. Pegg, Surf. Sci., 467, 118 (2000).

14. C. Lu, C. Rice, R.I. Masel, P.K. Babu, P. Waszczuk, and H.S. Kim, J. Phys. Chem. B, 106, 9581 (2002).

15. T. Frelink, W. Visscher, A.P. Cox, and J.A.R. Vanveen, Electrochim. Acta, 40, 1537 (1995).

16. C. Roth, N. Benker, T. Buhrmester, M. Mazurek, M. Loster, and H. Fuess, J. Am. Chem. Soc., 127, 14607 (2005).

17. P. Waszczuk, G.Q. Lu, A. Wieckowski, C. Lu, C. Rice, and R.I. Masel, Electrochim. Acta, 47, 3637 (2002).

18. D. Wang, L. Zhuang, and J. Lu, J. Phys. Chem. C, 111, 16416 (2007).

19. E. Antolini and F. Cardellini, J. Alloys Compd., 315, 118 (2001).

20. E. Antolini, F. Cardellini, L. Giorgi, and E.J. Passalacqua, $J$. Mater. Sci. Lett., 19, 2099 (2000).

21. Y. Liang, J. Li, Q.- C. Xu, R.-Z. Hu, J.-D. Lin, and D.-W. Liao, J. Alloys Compd., 465, 296 (2008).

22. S. Trasatti and GJ. Buzzanca, J. Electroanal. Chem., 29, A1 (1971).

23. D.R.M. Godoi, J. Perez, and H.M. Villullas, J. Phys. Chem. C, 113, 8518 (2009).

24. M. Watanabe and S. Motoo, J. Electroanal. Chem., 60, 267 (1975).

25. Z. Liu, X.Y. Ling, X. Su, and J.Y. Lee, J. Phys. Chem. B, 108, 8234 (2004).

26. A. Hamnett, Catalysis Today, 38, 445 (1997).

27. M. E. Labib, Colloids and Surfaces, 29, 293 (1988). 